\title{
Survival of translocated wild rabbits: importance of habitat, physiological and immune condition
}

\author{
S. Cabezas ${ }^{1}$, C. Calvete ${ }^{2} \&$ S. Moreno ${ }^{1}$ \\ 1 Doñana Biological Station (CSIC), Americo Vespucio Av., Seville, Spain \\ 2 Agroalimentary Technology Research Center of Aragon (CITA), Carretera de Montañana, Zaragoza, Spain
}

Keywords

habitat management; Myxomatosis;

Oryctolagus cuniculus; physiological

condition; rabbit haemorrhagic disease;

translocation.

\section{Correspondence}

Sonia Cabezas, Department of Biology, University of Saskatchewan, Saskatoon, SK, Canada S7N5E2.

Email: sonia.cabezas@usask.ca

\begin{abstract}
European wild rabbit populations are declining in Mediterranean ecosystems, where the species is of special conservation interest, and translocations are one of the most-used tools to recover populations. We evaluated the effects of habitat and physiological and immune condition on the short- and long-term survival of translocated adult wild rabbits. Rabbits were released in four different habitat treatments frequently used in conservation programmes: additional shelter, additional food, additional shelter plus food, predator exclusion and control. Before releasing the rabbits, we determined their physiological condition from body-mass and serum levels of urea, creatinine and total protein, and their immune condition from the concentrations of antibodies against myxomatosis and rabbit haemorrhagic disease. The risk of dying during the first 18 days post-release was two times lower in the predator exclusion treatment than that in the additional shelter, food, shelter plus food treatments and control. Short-term survival was also negative and positively correlated with creatinine and protein levels, respectively. The risk of dying from 19 to 180 days post-release in the additional food treatment was 10 and nine times lower than in predator exclusion and control, respectively, and negatively correlated with the antibody concentration against myxomatosis. The results suggest that short-term survival was related to predation risk and physiological condition, and long-term survival was related to food availability and myxomatosis incidence. We recommend that translocation programmes should consider using soft-release methods to reduce the risk of predation and ensure that all individuals are released in the best possible physiological condition to increase their short-term survival. We also suggest that the habitat be managed to ensure that the environment provides the appropriate conditions (i.e. food and shelter) for individuals and population persistence. Immune condition should be taken into account and translocation programmes should consider the origin of donor populations to reduce the variability of pathogen and virus strains.
\end{abstract}

\section{Introduction}

The European wild rabbit Oryctolagus cuniculus is a key species in Iberian Mediterranean ecosystems and is the main prey of at least 39 vertebrate predator species (Delibes \& Hiraldo, 1981). Over the last few decades, wild rabbit populations have declined or become extinct in parts of Europe and the Iberian Peninsula (Villafuerte et al., 1995; Moreno et al., 2007). This decline has been attributed to several causes, including fragmentation and loss of habitat and the emergence of two viral diseases: myxomatosis (1950s) and rabbit haemorrhagic disease (RHD) (late 1980s), which have led to a considerable reduction in rabbit population densities and significant changes in spatial distribution throughout Spain (Munoz, 1960; Calvete, Pelayo \& Sampietro, 2006; Delibes-Mateos, Ferreras \& Villafuerte, 2009). Currently, both myxomatosis and RHD are endemic in the Iberian Peninsula and cause high mortality rates in wild rabbit populations (Calvete et al., 2002).

Declines in rabbit populations have been especially serious in areas where the Spanish imperial eagle Aquila adalberti and the Iberian lynx Lynx pardinus coexist (Moreno et al., 2007). These top predators are well adapted to preying on this lagomorph (which comprises around $88 \%$ of their diets) and the decline in the number of rabbits is a principal factor increasing the risk of extinction of these species (Ferrer \& Negro, 2004). In addition, wild rabbit is the primary small-game species for sports hunting in Spain (Angulo \& Villafuerte, 2003; Calvete, Angulo \& Estrada, 2005).

Given the conservation interest of the species in Mediterranean ecosystems, resources are being devoted to improving wild rabbit populations via management strategies, such as habitat improvement (e.g. the creation of grazing areas, 
the building of artificial warrens and predator exclusion enclosures), disease control and the translocation of wild individuals (Angulo, 2003). For example, in Donana National Park (DNP) in south-west Spain, translocations of wild rabbit have been an established part of the management plan for the recovery of the Iberian lynx since 1993.

Translocation of wild animals is a strategy frequently used to manage and conserve natural populations (Griffith et al., 1989; Wolf et al., 1996). Despite the frequency of translocations, many are not successful and fail to establish selfsustaining populations (Griffith et al., 1989; Wolf et al., 1996; Seddon, Armstrong \& Maloney, 2007). In the case of wild rabbits, studies have shown that the elevated mortality that occurs during the first weeks after release is an important factor negatively affecting the success of translocations (Calvete et al., 1997; Letty et al., 2000; Letty et al., 2002). This mortality has been attributed to predation (Calvete et al., 1997) and deterioration of rabbit physiological condition as a consequence of the stress associated with introduction into unfamiliar environments (Letty et al., 2002; Letty et al., 2003).

Another crucial factor affecting the success of translocations is the characteristics of the release habitat (Macdonald et al., 2000; Seddon \& Ismail, 2002; Moorhouse, Gelling \& Macdonald, 2009). For a prey species, such as the rabbit, survival is closely related to habitat features. The habitat preferences shown by rabbits (e.g. scrub cover) are essentially conditioned by the risk of predation (Moreno, Villafuerte \& Delibes, 1996; Villafuerte \& Moreno, 1997). The success of translocations is also associated with habitat quality in terms of food availability. The survival of translocated individuals should vary according to the characteristics of the habitat of the release site: a trade-off between open areas with high availability of food and vegetation cover to minimize the predation risk.

The impact of myxomatosis and RHD on wild populations suggests that these diseases also significantly affect the success of translocations (Calvete et al., 2004a, 2004b; Moreno et al., 2004). The great majority of translocation programmes include the systematic immunization of all rabbits by vaccination and long-term survival of translocated rabbits could be associated with their antibody concentration at the time of release, which may subsequently decline (Fullagar, 1977; Ross et al., 1989; Simon et al., 1993). To date, no study has addressed this issue.

The present work aimed to examine the effects of several habitat treatments and the level of immunity against myxomatosis and RHD on the survival of translocated rabbits, after controlling for individual physiological condition. The objectives were (1) to evaluate the short- and longterm survival rates and causes of mortality in rabbits released in conservation programmes using the most frequently applied habitat treatments (additional shelter, additional food availability, additional shelter plus food availability and predator exclusion); (2) to evaluate the effect of individual physiological condition before release on short-term survival; (3) to evaluate the effect of immune condition, measured as the concentration of antibodies against myxomatosis and RHD, on long-term survival.

\section{Methods}

\section{Study area}

Translocations were conducted in SW Spain in a site known as El Abalario in DNP ( $37110^{\circ}$ latitude $\mathrm{N}$ and $6145^{\circ}$ longitude $\mathrm{W}$ ). This study was within the framework of a recovery project of the Iberian lynx and the study area is one of the few areas where the Iberian lynx still exist. The substrate is dominated by an elevated layer of quaternary aeolian sands with high dunes near the Atlantic coast. Over $43 \%$ of the surface is occupied by Mediterranean shrubland (Fernandez, 2005) composed of Cistaceae (Halimium halimifolium, Halimium commutatun and Cistus libanotis) and Labiate (Rosmarinus officinalis) species. Wooded areas consisted of reforested umbrella pines Pinus pinea, which were cultivated from the 1940 s to the late 1980s, resulting in landscape transformation that reduced the original heterogeneity of the habitat (Fernandez, 2005). The dry sandy soil has resulted in the area being typically sparse in natural grasslands. In fact, our study area had the lowest percentage of grassland in DNP: only $7 \%$ of the surface was occupied by natural pastures compared with $26 \%$ and $15 \%$ found in Coto del Rey and Biological Reserve, respectively (Fernandez, 2005).

\section{Treatment applied to release habitat}

We defined 10 open square plots (4 ha each) separated from each other by a distance of between 1 and $6 \mathrm{~km}$. The 10 plots had a homogeneous habitat in terms of type of vegetation (Fernandez, 2005). Two plots were not treated and were used as experimental habitat controls. In the remaining eight plots, we applied habitat treatment types most frequently used in rabbit conservation programmes: (1) additional shelter: refuge availability seems to limit rabbit abundance in DNP (Lombardi et al., 2003). Warrens are used for protection from predators and weather and are particularly important for breeding (Villafuerte, 1994). In sandy environments, natural warrens often fail because they sink or are dug by predators (Palomares, 2003). Shrub cover, important for protection against predators, provided a suitable cover for rabbits in the study area (Fernandez, 2005). Warren availability is important for reproduction, and recovery measures for wild rabbit populations often include the installation of warrens (Catalan, RodriguezHidalgo \& Tortosa, 2008). In two of the eight plots, we constructed eight artificial warrens (for further details, see Cabezas \& Moreno, 2007); (2) additional food availability: pasture availability is a limiting factor for the rabbit population in this area, where the percentage of natural grassland is low (Fernandez, 2005). In DNP, the diet of rabbits is dominated by annual plants (Soriguer, 1988) and abundance has been associated with the quality and quantity of protein availability in the diet as determined by the germination and growth of herbaceous plants (Villafuerte, Lazo \& Moreno, 1997). The conservation of pastures and the increase of the total surface covered by annual plants have been proposed as important measures to improve the rabbit populations and 
the success of rabbit reintroductions in DNP (Villafuerte et al., 1997). In two plots, we sowed every year in autumn an area of 1 ha with the herbaceous crops barley Hordeum vulgare and oats Avena sativa. According to Fernandez's (2005) data, the pasture cover in the study area was over $7 \%$; therefore, we can assume that the food availability increased c. $23 \%$ in this treatment, that is, the grassland cover was increased by approximately three to four times; (3) additional shelter plus food availability: in two other plots, we combined the two previous treatments; we built eight artificial warrens and sowed an area of 1 ha with herbaceous crops; (4) predator exclusion: to evaluate the impact of predation, we excluded terrestrial predators by building a $2 \mathrm{~m}$ high perimeter wire fence with a simple mesh of $50 \mathrm{~mm}$. This first fence was reinforced with a second, $1 \mathrm{~m}$ high fence ( $30 \mathrm{~mm}$ mesh) with $50 \mathrm{~cm}$ under the ground to prevent rabbits and carnivores getting through. These fences were also equipped with several horizontal electrified wires. Habitat treatments and control were randomly assigned to plots. The profitability of these treatments on rabbit populations in this area has already been evaluated by Cabezas \& Moreno (2007).

\section{Origin of individuals and quarantine period}

Between 1999 and 2002, six translocation experiments with wild rabbits were carried out (see Table 1). Rabbits were brought from various sites in the provinces of Cadiz and Huelva (both SW Spain) located from 44 to $250 \mathrm{~km}$ away from the recipient population in DNP. The donor populations were genetically similar to the recipient one (Branco, 1995). After capture, and according to the translocation protocols established by conservation programmes in DNP, rabbits were kept in quarantine until their release (Calvete et al., 2005). All animals were housed individually in flat deck-type cages commonly used for the commercial breeding of domestic rabbits. At the beginning of the quarantine period, all rabbits were sexed and identified by a small numbered metal tag placed in the earflap. Subsequently, all individuals were vaccinated sub-cutaneously against both myxomatosis and RHD with commercial vaccines at doses recommended for domestic rabbits (myxomatosis: live Shope fribroma virus Mixohipra-FSA, Hipra Laboratory, Gerona, Spain; RHD: ARVILAP, Ovejero Laboratory,
Leon, Spain), and subjected to internal and external deparasitization including subcutaneous inoculations against nematodes with levamisol (Nemisol, Ovejero Laboratory, Leon, Spain) and cestodes with praziquantel (Droncit, Bayer Hispania Laboratory, Barcelona, Spain) and the oral administration of triclabendazole against trematodes (Fasinex, Novartis Farmaceutica Laboratory, Barcelona, Spain). We evaluated the antibody concentration against myxomatosis and RHD in the serum before vaccination and found that the initial prevalence of antibodies varied among experimental batches, ranging from 36 to 91\% for myxomatosis and from 13 to $82 \%$ for RHD. The mean percentage of rabbits that seroconverted after vaccination was $81 \%$ for myxomatosis and $84 \%$ for RHD (see Cabezas, Calvete \& Moreno, 2006). The quarantine period ranged from 2 to 4 weeks to account for myxomatosis and RHD incubation periods and the time following vaccination needed to develop immunity against these diseases (Arguello, 1991). At the end of quarantine period and 1 day before release into the new habitat, a blood sample was taken from each rabbit to determine biochemical and immunological parameters that were subsequently analysed with survival. Complementary to biochemical parameters, body mass was also recorded to evaluate the physiological condition of every rabbit.

\section{Biochemical and immunological analysis}

From the serum obtained from blood samples at the end of the quarantine period, the levels of three biochemical parameters, urea nitrogen, creatinine and protein, were determined by means of spectrophotometric procedures and commercial kits (Sigma Diagnostics, Madrid, Spain). These biochemical parameters were used because they are indicators of tissue catabolism and nutritional status, and are good estimators of physiological condition (Harder \& Kirkpatrick, 1994; Stirrat, 2003). Moreover, they have been used as estimators of physiological stress and survival probabilities in translocated wild rabbits (Calvete et al., 2005). Serum antibody concentrations against myxomatosis and RHD were determined by enzyme-linked immune-absorbent assays using commercial kits (myxomatosis: CIVTest cuni; Hipra Laboratory, Gerona, Spain; RHD: Ingezim rabbit; Ingenasa Laboratory, Madrid, Spain). The antibody concentrations were expressed as a

Table 1 Number of radio-tagged European wild rabbits Oryctolagus cuniculus released into each of the eight habitat treatment plots: two with additional shelter, two with additional food, two with additional shelter plus food, two with predator exclusion and two habitat control (no treatment)

\begin{tabular}{|c|c|c|c|c|c|c|c|c|c|c|}
\hline \multirow[b]{3}{*}{ Translocation experiments } & \multicolumn{10}{|c|}{ Habitat treatment plots } \\
\hline & \multicolumn{2}{|c|}{ Shelter } & \multicolumn{2}{|c|}{ Food } & \multicolumn{2}{|c|}{ Shelter+food } & \multicolumn{2}{|c|}{ Predator exclusion } & \multicolumn{2}{|c|}{ Control } \\
\hline & 1 & 2 & 1 & 2 & 1 & 2 & 1 & 2 & 1 & 2 \\
\hline First: November 1999 & 10 & 0 & 10 & 0 & 10 & 0 & 10 & 0 & 10 & 0 \\
\hline Second: February 2000 & 10 & 0 & 10 & 0 & 10 & 0 & 10 & 0 & 10 & 0 \\
\hline Third: December 2000 & 0 & 10 & 0 & 10 & 0 & 10 & 0 & 10 & 0 & 10 \\
\hline Fourth: February 2001 & 0 & 14 & 0 & 14 & 0 & 14 & 0 & 10 & 0 & 14 \\
\hline Fifth: January 2002 & 0 & 10 & 0 & 10 & 0 & 10 & 0 & 0 & 0 & 10 \\
\hline Sixth: March 2002 & 0 & 10 & 0 & 10 & 0 & 10 & 0 & 0 & 0 & 10 \\
\hline
\end{tabular}


Relative Index of Immunity (RI), in which the optical density (OD) of each sample was related to the ODs of positive and negative controls. RI values ranged from 1 to 10 , and sera were scored, with RIZ2 as positive (Pages, Artigas \& Espuna, 1991). Rabbits with RIZ2 had experienced effective contact with a wild viral antigen before vaccination.

\section{Translocation experiments and monitoring}

The first and second translocations were carried out in five of the 10 experimental plots: in one of each of the treatments type (shelter, food, shelter plus food and predator exclusion) and in one habitat control (Table 1). The third and fourth translocations were carried out in five additional plots in which there were no previous translocations (Table 1). Finally, the fifth and sixth translocations were carried out in same plots used for the third and fourth but without the exclusion of predator treatment (Table 1). Between 31 and 34 adult rabbits chosen at random were released per translocation and per plot (see Table 1) with a sex ratio of c. 1:1. Of these, between 10 and 14 individuals per plot (chosen at random and with sex ratio 1:1) were fitted with a radiotracking collar that weighed c. $20 \mathrm{~g}$ and contained an activity sensor (Biotrack, Wareham, UK). Rabbits were released directly into the chosen habitat (approximately in the centre of the plot) in groups of three to four individuals distributed homogenously throughout the scrub. In the plots with artificial warrens, rabbits were released inside of warrens.

After release, radio-tagged rabbits were relocated on a daily basis by means of telemetry location receivers and a hand-held antenna, which were able to determine rabbits' spatial position and whether they were dead or alive. Causes of mortality were determined by examination of carcasses and remains (e.g. bite marks on the body and/or radiocollar), the location of dead animals and other signs, such as feathers, faeces or tracks that could provide a clue as to the cause of death or the identity of the predator. Rabbits found dead were classified into two categories: predation or disease. Death by predation was determined when a carcass had evident signs of predation by raptors (evidence of feathers, tufts of hair and remains of long bones) or by mammalian carnivores (incisor marks on collars, scars and caecum or sometimes buried or half-buried corpses). Death by disease was determined by post mortem examination where external lesions due to myxomatosis or RHD were found. When possible, a direct haemagglutination test was applied to detect RHD antigens in liver tissues. Finally, when the radio-collar stopped emitting and there was no information about the cause of mortality, we assigned the category 'unknown' and these were considered censored data in the survival models.

\section{Statistical analysis}

Daily and cumulative mortality and survival rates were calculated using the MICROMORT software program described in Heisey \& Fuller (1985). This program uses the d-method approximation to compute standard errors for estimated rates, and provides a Z-test to compare pairs of rates. Given that mortality occurring during the first weeks has been attributed to different causes (i.e. predation and deterioration of rabbit physiological condition; Calvete et al., 1997; Letty et al., 2002; Letty et al., 2003) than long-term mortality, we analysed short- and long-term periods separately. A piecewise linear regression model was used to calculate this breakpoint. Post-release days and daily mortality rates were included in the model as dependent and predictor variables, respectively, and on the basis of these results, both shortand long-term periods were determined.

The association between survival and the treatments applied to the release habitat, physiological condition and antibody concentration against myxomatosis and RHD was determined by using four Cox's proportional hazard regression models for censored data. The model can be expressed as $h(t, z)=h_{0}(t) \times \exp \left(b^{0} \mathrm{z}\right)$, where $h(t, z)$ is the hazard rate, contingent on a particular covariate vector $\mathrm{z}, \mathrm{h}_{0}(\mathrm{t})$ is referred to as the baseline hazard, that is, it is the hazard rate when the values for all independent variables (i.e. in z) are equal to zero, and $\mathrm{b}$ is the vector of regression coefficients (see Therneau \& Grambsch, 2001). A minimum adequate final model was obtained using a backward selection procedure based on the likelihood ratio test (LRT) and where only significant explanatory variables were retained. We included the release batch in all models as a predictive variable to control the potential effect of the date of release and replicate on survival. Model 1 evaluated short-term survival, controlling by body mass and biochemical parameters (urea nitrogen, creatinine and total protein) associated with physiological condition, the treatment of habitat (as a qualitative variable with five levels) and sex. Models 2 and 3 had the same variables as Model 1, although in Model 2, only the cause of mortality by predation was tested and the rest of the causes of mortality were censored, while in Model 3, only the causes of mortality by disease were tested and the other causes were censored.

Model 4 evaluated the long-term survival, controlling the effects of the antibody concentration against myxomatosis and RHD and the habitat treatment. Sex was also included in this model.

Given that some translocated rabbits left the treatment plot in which they were released, in the survival analyses, we included the number of radio-days that each rabbit was inside the treatment plot, and once they left, they were classified as censored data.

\section{Results}

As is usual in rabbit translocations, an earlier post-release period with high mortality rates was observed (Fig. 1). Establishing the breakpoint at day 18 post-release yielded an optimal goodness of fit to the piecewise linear regression model that explained $95.4 \%$ of variance accounted for in mortality variation across time. Thus, the interval of between 0 and 18 days after release was established as the short-term period. This interval is similar to short-term periods established in other studies of wild rabbit translocations (Letty et al., 2002; Letty et al., 2003; Calvete et al., 2005). To avoid the interference of factors that might affect 


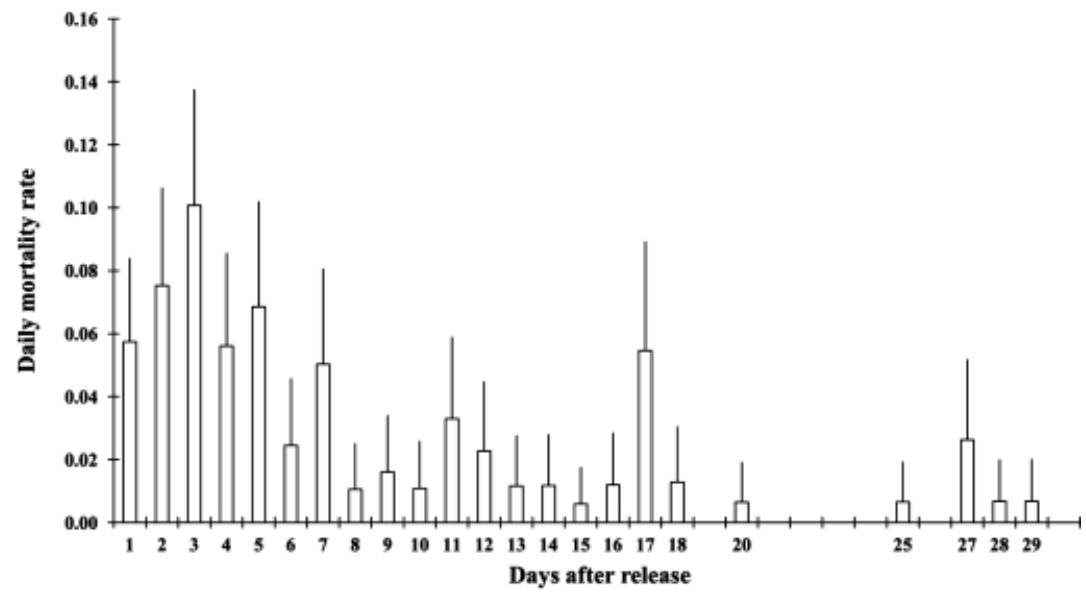

Figure 1 Daily mortality rate (with 95\% confidence intervals) of translocated rabbits for all release batches combined, up to 30 days after release.
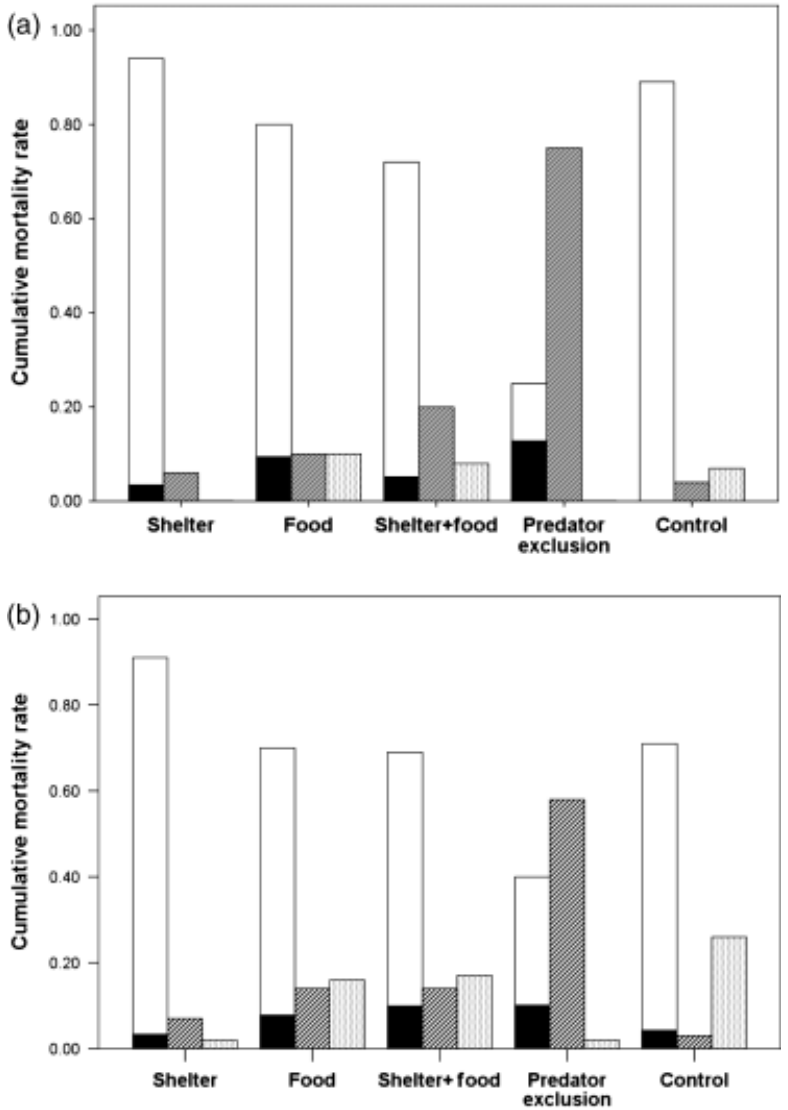

Figure 2 Cumulative mortality rates of translocated rabbits associated with each cause of death under the different treatment types (a) in the short term and (b) in the long term. Bars indicate the causes of death (white and black: predation, white: predation by mammalian carnivores, black: predation by raptors; lined: disease; dotted: unknown).

short-term survival in the long-term analysis, the first 18 days were excluded from long-term analyses. This way, the interval for estimating long-term survival was established from day 19 to day 180. The upper limit of this interval was established at 180 days because from this time onwards the effectiveness of the vaccine against RHD begins to decrease and the probability of infection increases (Muguruza et al., 1993). Additionally, from 180 days after release onwards, the sample size of wild rabbits was not large enough in all plots to establish suitable comparisons.

The results showed that, of the 296 radio-tagged rabbits in all the release translocation experiments $69 \%$ died as a result of predation, of which $87 \%$ were killed by mammalian carnivores and the remaining $13 \%$ by raptors. Forty-three rabbits $(15 \%)$ died of disease and $48(16 \%)$ of unknown causes. Forty-eight percent of rabbits (142 individuals) died during the first 18 days of survey: $77 \%$ died as a result of predation, of which $93 \%$ were killed by mammalian carnivores (including 40 found buried or half-buried with evident signs of predation by foxes) and $7 \%$ by raptors; $17 \%$ died of disease and $6 \%$ of unknown causes. Figure 2 shows the cumulative mortality rates associated with each cause of death under the different treatment types for the first 18 days and for the entire survey period.

The distribution of biochemical parameters, body mass and antibody concentration against myxomatosis and RHD of rabbits before release in the four habitat treatments and control plots is given in Table 2. Only creatinine showed significant differences among treatments: rabbits released in the increased food treatment had higher creatinine levels before release than those released in shelter and predator exclusion treatments (Table 2).

Model 1 showed that the short-term survival varied from one treatment to another $\left(\mathrm{R}^{2}=0.05\right.$; $\mathrm{LRT}=4.4$, d.f. $=4$; $\mathrm{P}=0.035)$. The model calculated an estimate of the risk of dying (expB) and 95\% confidence intervals (CI) for this risk. Thus, the risk of dying in the predator exclusion treatment was 1.94 (CI: 1.06-3.58; $\mathrm{P}=0.03$ ), 2.03 (CI: 1.07-3.84; $\mathrm{P}=0.03$ ), 1.88 (CI: 0.99-3.58; $\mathrm{P}=0.05$ ) and 1.39 (CI: $0.71-2.74 ; \mathrm{P}=0.33$ ) times lower than in additional shelter, additional food, additional shelter plus food treatments and control, respectively. Moreover, the risk of dying in control plots was 1.39 (CI: 0.77-2.51; $\mathrm{P}=0.27$ ), 1.45 (CI: 0.78-2.70; $\mathbf{P}=0.23$ ) and 1.35 (CI: $0.72-2.51 ; \mathrm{P}=0.35$ ) times lower than in additional shelter, additional food supply and 
Table 2 Distribution of biochemical parameters, body mass and antibody concentration against myxomatosis and RHD (expressed as a relative index of immunity) of rabbits before release into the four habitat treatments and control

\begin{tabular}{|c|c|c|c|c|c|c|c|c|c|c|c|c|c|c|c|c|}
\hline & \multicolumn{15}{|c|}{ Habitat Treatment Plots } & \multirow[b]{3}{*}{$P$} \\
\hline & \multicolumn{3}{|c|}{ Shelter } & \multicolumn{3}{|c|}{ Food } & \multicolumn{3}{|c|}{ Shelter+food } & \multicolumn{3}{|c|}{ Predator exclusion } & \multicolumn{3}{|c|}{ Control } & \\
\hline & $\mathrm{n}$ & Mean & SE & $\mathrm{n}$ & Mean & SE & $\mathrm{n}$ & Mean & SE & $\mathrm{n}$ & Mean & SE & $\mathrm{n}$ & Mean & SE & \\
\hline Urea $(\mathrm{mg} / \mathrm{dl})$ & 44 & 26.95 & 1.37 & 38 & 26.73 & 1.24 & 37 & 27.03 & 0.91 & 28 & 24.80 & 1.18 & 33 & 26.80 & 1.06 & 0.731 \\
\hline Creatinine (mg/dl) & 42 & 0.63 & $0.05^{\mathrm{a}}$ & 34 & 0.99 & $0.16^{\mathrm{b}}$ & 35 & 0.80 & $0.03^{\mathrm{ab}}$ & 25 & 0.57 & $0.04^{\mathrm{a}}$ & 26 & 0.76 & $0.05^{\mathrm{ab}}$ & 0.005 \\
\hline Protein (g/dl) & 44 & 6.26 & 0.14 & 38 & 6.37 & 0.13 & 37 & 6.72 & 0.17 & 28 & 6.80 & 0.28 & 33 & 6.66 & 0.22 & 0.159 \\
\hline Body Mass (g) & 47 & 937.02 & 18.65 & 40 & 991.50 & 17.86 & 39 & 977.82 & 14.39 & 37 & 960.95 & 16.17 & 36 & 953.19 & 17.18 & 0.169 \\
\hline $\mathrm{RHD}$ & 44 & 8.33 & 0.38 & 36 & 7.41 & 0.58 & 38 & 8.31 & 0.46 & 31 & 7.15 & 0.63 & 35 & 7.64 & 0.59 & 0.385 \\
\hline Myxomatosis & 44 & 7.53 & 0.45 & 36 & 7.61 & 0.49 & 38 & 7.20 & 0.49 & 30 & 8.79 & 0.46 & 35 & 7.40 & 0.49 & 0.210 \\
\hline
\end{tabular}

We determined $\mathrm{P}$ values for the variation of mean differences among treatments. Post hoc contrasts among treatments are shown with superscript and habitat treatments which do not share the same letter are significantly different.

additional shelter plus food treatments, respectively. Shortterm survival was negatively correlated with creatinine $(\mathrm{LRT}=4.3$; d.f. $=1 ; \mathrm{P}=0.038)$ and positively correlated with the total protein (LRT $=3.8$; d.f. $=1 ; \mathrm{P}=0.051$ ) concentrations before release. Urea nitrogen, sex and batch were not retained in the model.

The short-term survival as a result of predation (Model 2) was also different among treatments $\left(\mathrm{R}^{2}=0.06\right.$; $\mathrm{LRT}=8.4$ d.f. $=1 ; \mathrm{P}=0.004)$ and negatively correlated with serum creatinine levels (LRT $=4.7$ d.f. $=1 ; \mathrm{P}=0.031$ ). The risk of dying in the predator exclusion treatment was 7.48 (CI: 2.62-21.3; PO0.01), 6.63 (CI: 2.25-19.5; PO0.01), 5.75 (CI: 1.93-17.1; PO0.01) and 5.25 (CI: 1.77-15.6; PO0.01) times lower than in additional shelter, additional food, additional shelter plus food treatments and control, respectively. However, the cause of mortality by disease (Model 3) was not associated with any variable in the model. The batch of release was not retained in Model 2 or 3.

The long-term survival (between 19 and 180 days) was also associated with the habitat treatment $\left(\mathrm{R}^{2}=0.04\right.$; $\mathrm{LRT}=5.8$; d.f. $=4 ; \mathrm{P}=0.016$ ) and positively correlated with myxomatosis antibody concentrations before release (LRT $=3.8$; d.f. $=1$; $\mathrm{P}=0.051)$. The risk of dying in the additional food treatment was 10.17 (CI: 1.21-85.78; $\mathbf{P}=0.03$ ), 8.88 (CI: 1.102; $\mathrm{P}=0.04$ ), 5.90 (CI: 0.69-50.81; $\mathrm{P}=0.11$ ) and 4.01 (CI: 0.44-36.16; $\mathrm{P}=0.22$ ) times lower than in predator exclusion, control plot, shelter plus food and shelter treatments, respectively. In this model sex, RHD antibody concentration or batch were not retained in the model.

Figure 3 shows the relative risk of dying in each treatment: (1) in the short term, when individuals had high, medium and low physiological conditions (combining minimum, mean, and maximum concentration of protein and creatinine)

$$
\begin{aligned}
& \mathrm{H} ð 18 \mathrm{p}=\mathrm{h}_{0} \partial 18 \mathrm{p} 1 / 4 \exp 1 / 20 \mathrm{~B}_{\text {ðproteinp }} \times \text { protein valuep }
\end{aligned}
$$

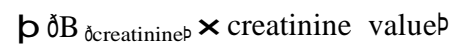

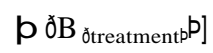

(2) In the long term, when individuals had high, medium and low immune conditions (minimum, mean, and max-
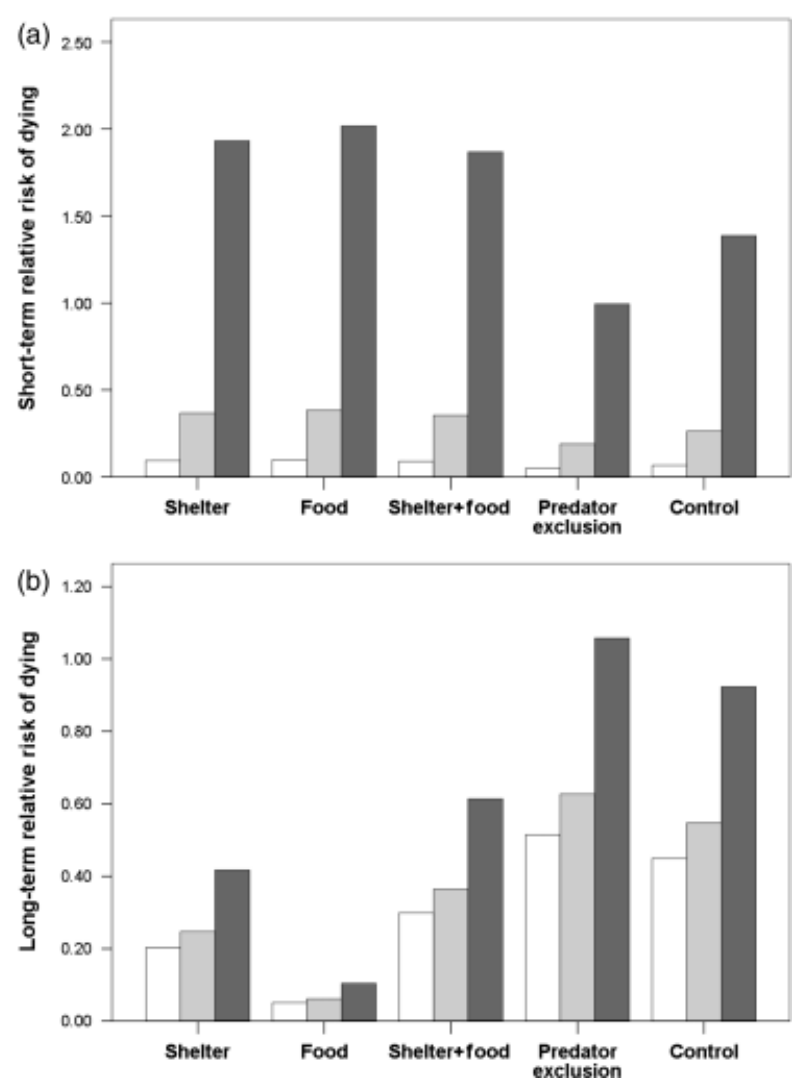

Figure 3 Relative risk of dying in each treatment (additional shelter, additional food, additional shelter plus food, predator exclusion) and control plots. The relative risk of dying is given by the equation $\mathrm{H}(\mathrm{t}) /$ $h_{0}(t)=\exp (A)$. (a) Shows the short-term risk of dying when rabbits had high (white bars), medium (light grey bars) and low (dark grey bars) physiological condition. (b) Shows the long-term risk of dying when rabbits had high (white bars), medium (light grey bars) and low (dark grey bars) immune condition.

imum concentration of antibodies against myxomatosis)

$\mathrm{H} \partial 180 \mathrm{p}=\mathrm{h}_{0} \partial 180 \mathrm{p} 1 / 4 \exp ^{1 / 2} \mathrm{~B}_{\text {ðmyxomatosisp }} \times$ myxomatosis valuep

$$
\left.\mathrm{p} \partial \mathrm{B}_{\text {ðtreatmentp }} \mathrm{P}\right]
$$




\section{Discussion}

Rabbit survival was low during the first 18 days after release (daily survival rate $\mathrm{TSE}=0.79 \mathrm{~T} 0.02$ ). This result was probably due in part to the attraction that the simultaneous release of a large number of rabbits into a small area exerted on predators. This type of behaviour, known as multiple predation or surplus killing (Short, Kinnear \& Robley, 2002), has also been found in others studies of wild rabbit translocations (Calvete et al., 1997; Calvete et al., 2002; Moreno et al., 2004).

As expected, surplus killing did not occur in the predator exclusion treatment and fencing caused a reduction in mortality. Of 16 rabbits killed by predation in this treatment, 13 were killed by raptors, and this cause had greater mortality rates $(81 \%)$ in this treatment than in all the other treatment types. Despite there being a low abundance of raptors in the study area (S. C. pers. obs.), it is likely that the rabbit concentration in the predator exclusion treatment provided raptors with an optimal hunting area and with less competition from other carnivores. Curiously, three rabbits were able to get through the electric fence and were killed by foxes outside the plot; the occasional permeability of electric fences has been described in other studies (McKillop et al., 1998; Calvete \& Estrada, 2004).

Disease was the main cause of mortality found in the predator exclusion treatment: $75 \%$ during the first 18 days and $58 \%$ throughout the entire survey period. However, in the rest of the treatment plots, the main cause of mortality was predation by carnivores. Differences found between the predator exclusion treatment and the rest of the treatments suggest that the impact of predation may have been overestimated, as diseased rabbits or those with lower physiological condition were more vulnerable to predators. The overestimation of predation, or rather the underestimation of diseases, is unavoidable when working with this kind of methodology, especially with a prey species (Griffith et al., 1993; Wolf et al., 1996; Letty et al., 2003; Calvete \& Estrada, 2004; Calvete et al., 2005).

Short-term survival was associated with the release habitat. Thus, individuals released in the predator exclusion treatment showed greater cumulative survival rates than those released in the additional shelter, food and shelter plus food treatment plots (Table 3). Survival was higher in the predator exclusion treatment plot during the first 18 days after release because mammalian predators were unable to enter. This result suggests that predation played an important role in release areas. The short-term survival was also negatively correlated with the creatinine and positively correlated with the total protein concentrations found before release. Creatinine blood concentrations may increase through catabolism in tissues as a response to stress (Jacobson, Kirkpatrick \& McGinnes, 1978; Amici et al., 2000) and can be used as an indicator of muscle damage. Elevated levels are associated with reduced food intake, body-mass loss and decreases in body fat and proteins (DelGiudice, Mech \& Seal, 1990). Moreover, the quantity of protein consumed can also be positively associated with total serum protein levels (Warren \& Kirkpatrick, 1978). Our results showed that rabbits with higher creatinine and lower total protein concentrations before release had lower survival in the short term. Figure 3 illustrates the effect size among variables. Figure 3a suggests that the short-term relative risk of dying was mainly associated with the physiological condition and rabbits with lower physiological condition showed a higher risk of dying in all the treatments. The relative risk of dying in the predator exclusion treatment was approximately two times lower than in the rest of the treatments when rabbits had low, medium or high physiological condition. These results support the hypothesis that rabbit physiological condition can modulate survival after release, in accordance with previous work (Letty et al., 2002; Calvete et al., 2005). Contrary to expectations, urea nitrogen was not retained in the short-term survival model. This result could be due to the correlation found between urea nitrogen and creatinine and urea nitrogen and total protein (t-test $=4.70$, PO0.001; t-test $=2.96$, $\mathrm{P}=0.004$, respectively), which may have resulted in only two of the biochemical variables being retained in the model. When urea nitrogen was tested in the model without the other two biochemical variables, it was negatively associated with survival (LRT $=5.70 ; \mathrm{P}=0.017$ ), supporting the results reported previously (Calvete et al., 2005).

Long-term survival was also associated with the habitat treatment. Individuals released in the additional food availability treatment showed higher long-term survival than those released in the predator exclusion treatment and control plots (Table 3). Figure $3 \mathrm{~b}$ suggests that the relative risk of dying in the long term was associated with a greater degree with the treatment than it was with the immune condition. Our result suggests that the improvement of the habitat quality in terms of food availability had a positive

Table 3 Short- and long-term cumulative survival rate, standard error (SE) and total number of dead rabbits in additional shelter, additional food, additional shelter plus food, predator exclusion treatments and habitat control plots

\begin{tabular}{lllllll}
\hline & \multicolumn{2}{l}{ Short-term survival rate } & & \multicolumn{2}{l}{ Long-term survival rate } \\
\cline { 2 - 3 } & \# Deaths & Estimate & SE & & \# Deaths & Estimate \\
\hline Shelter & 34 & 0.34 & 0.05 & 15 & 0.32 & 0.60 \\
Food & 31 & 0.34 & 0.05 & 9 & 0.07 \\
Shelter+food & 36 & 0.37 & 0.05 & 16 & 0.41 & 0.09 \\
Predator exclusion & 16 & 0.62 & 0.07 & 15 & 0.45 & 0.36 \\
Control & 24 & 0.53 & 0.06 & 21 & 0.06 \\
\hline
\end{tabular}


effect on rabbit survival and supports the findings reported by other studies (Villafuerte \& Moreno, 1997; Moreno et al., 2004; Fernandez, 2005). According to Fernandez (2005), in our study area, over $7 \%$ of the surface was occupied by pasture cover. Therefore, after we sowed ( 1 of 4 ha plot), we can assume that food availability increased approximately three to four times, which probably improved the rabbits' physiological condition and consequent survival. Moreover, food availability has been positively associated with rabbit survival because it reduces the rabbits' need to move to find food and therefore they will be less exposed to predators (Moreno et al., 2004). However, rabbits released in the shelter plus food treatment did not have greater survival probabilities in the long term. This could be due to the fact that the combination of both treatments reduced shrub cover (in part caused by the movement and transit of machines used to build them) more than in food or shelter treatments separately, and this shrub cover reduction increased the risk of predation (Moreno et al.,1996; Villafuerte \& Moreno, 1997; Lombardi et al., 2003). Our result would be consistent with Fernandez's (2005) finding that rabbit abundance in this area was linearly correlated with the density of shrub-pasture ecotones and non-linearly correlated with the mean landscape shrub cover. Abundance was higher at intermediate shrub cover values (Fernandez, 2005). Another possible explanation could be that the presence of large artificial warrens (eight warrens per plot with an area of between 20 and $30 \mathrm{~m}^{2}$ each) that were used by rabbits (S. Cabezas et al., unpubl. data) attracted predators and therefore increased rabbit mortality in the treatment.

Long-term survival was positively correlated with the myxomatosis antibody concentrations before release and after vaccination. This result suggests that myxomatosis is probably still an important cause of mortality in wild rabbit populations, although its real impact is hard to assess because most of the symptoms of the disease are chronic or sub-acute and predators often kill sick rabbits that would have died of the disease anyway (Temple, 1987; Calvete et al., 2002). Myxomatosis and RHD are endemic diseases in the Iberian Peninsula and periodic outbreaks occur with an epidemiological pattern characterized by high antibody prevalence in adult individuals (Calvete et al., 2002; Calvete et al., 2004b). Cabezas et al. (2006) showed for the same individuals in the present study that $95 \%$ of rabbits were seropositive against myxomatosis after vaccination (79\% were seropositive before vaccination), although variations in the values of antibody concentrations were found. Others studies have shown a positive relationship between myxomatosis antibody concentrations and the survival rates of wild rabbits (Cooke \& Berman, 2000; McPhee et al., 2002). In our study, the relationship between myxomatosis antibody concentrations and survival rates was not due to the fact that seronegative individuals had lower survival, as among these rabbits, the survival rates were as variable as seropositive. A possible hypothesis is that the myxomatosis virus re-infected translocated individuals, because the antibody concentrations in animals recovering from myxoma- tosis epizootics decrease with time and therefore individuals become more vulnerable to re-infections (Fullagar, 1977; Cooke \& Fenner, 2002). Moreover, resistance to a type of viral strain is only partially specific and, if there is contact with a different virus, strain individuals can be re-infected if immunity is not complete. Some studies have shown that in natural populations, cases of re-infections might exist that cause pathological symptoms more or less slight of the disease (Fullagar, 1977; Ross et al., 1989).

The immune level against RHD was not associated with long-term survival, as has been shown by other studies (Calvete et al., 2004a; McPhee et al., 2009). The monitoring period probably was not long enough to detect the impact of annual RHD outbreak in winter among translocated rabbits (Calvete et al., 2002; Moreno et al., 2004).

Our study adopted an experimental approach to evaluating the survival of translocated wild animals. The results from this study may have important implications for wild rabbit population management techniques and for the translocation of other wild species. In conclusion, our results suggest that the short-term survival of translocated rabbits was associated with individual physiological condition. Handling and restraining processes as a consequence of capture, transport and especially the subsequent quarantine period can cause high levels of stress in wild animals and consequently the deterioration of their physiological condition (Woodford \& Rossiter, 1993; Letty et al., 2000; Calvete et al., 2005). However, the possible transmission of new disease agents into the release area is of primary importance because these diseases may have a major impact on native species (Viggers, Lindenmayer \& Spratt, 1993; Wolf et al., 1996). While some controversy exists regarding whether or not wild animals should be kept in quarantine before being released, it is clear that the consequences should be evaluated before making a decision. Translocation programmes must take into account the trade-off between minimizing disease risks in the native and translocated species and the effects of the quarantine period on the health and survival of the translocated species. Also, short-term survival was related to the risk of predation. We suggest that soft-release methods should be used instead of traditional protocols to reduce the risk of predation (Calvete \& Estrada, 2004). For example, it has been shown that releasing rabbits into a fenced warren for the few first days reduces both their dispersal and the negative impact of predation (Calvete \& Estrada, 2004). Long-term survival was associated with the habitat treatment, suggesting that the quality of the release habitat has important implications for the translocated animal survival. Rabbit translocations programmes should therefore be carried out in conjunction with improvements in release habitat. Finally, long-term survival was determined by myxomatosis incidence. This result suggests that rabbits should be released with good immune condition against both diseases. Therefore, if donor populations have low antibody prevalence, vaccination protocols could be applied before translocation. Moreover, the infection of translocated individuals with different local viral strains is a 
possible hypothesis that explains our result. We suggest that translocation programmes should consider the origin of donor populations to reduce the variability of pathogen and virus strains.

\section{Acknowledgements}

We thank A. Melero, L. Lombardi, P. Rubio, R. Moreno and D. Doblas for their help during data collection, and Drs E. Angulo, M. Delibes and J. Blas for their useful comments, and three anonymous referees improved the paper with their comments and suggestions. G. Fairhurst kindly revised the English. Dr R. Villafuerte kindly allowed us to perform the laboratory analyses at the Instituto de Investigacion en Recursos Cinegeticos (IREC). The staff of Donana Natural Park provided technical and logistical support. The research was supported by FEDER (1FD1997-0789) and MCYT (BOS2001-2391-C02-01) projects.

\section{References}

Amici, A., France, O., Mastrodiacono, P., Merendino, N., Nardini, M. \& Tomais, G. (2000). Short term acute heat stress in rabbits: functional, metabolic and immunological effects. World Rabbit Sci. 3, 11-16.

Angulo, E. (2003). Factores que afectan a la distribución y abundancia del conejo en Andalucía. PhD thesis, Madrid Complutense University, Madrid.

Angulo, E. \& Villafuerte, R. (2003). Modelling hunting strategies for the conservation of wild rabbit populations. Biol. Conserv. 115, 291-301.

Arguello, J.L. (1991). La enfermedad hemorragica viral del conejo: vacunacion y repuesta inmune. Rev. Sci. Tech. Office Int. Epizoot. 10, 459-470.

Branco, M. (1995). Contribuçao para o estudo da genética bioquímica e populacional do coelho, Oryctolagus cuniculus. $\mathrm{PhD}$ thesis, University of Porto, Porto.

Cabezas, S., Calvete, C. \& Moreno, S. (2006). Vaccination success and body condition in the European wild rabbit: applications for conservation strategies. J. Wildl. Mgmt. 70, 154-160.

Cabezas, S. \& Moreno, S. (2007). An experimental study of translocation success and habitat improvement in wild rabbits. Anim. Conserv. 10, 340-348.

Calvete, C., Angulo, E. \& Estrada, R. (2005). Conservation of European wild rabbit populations when hunting is age and sex selective. Biol. Conserv. 121, 623-634.

Calvete, C., Angulo, E., Estrada, R., Moreno, S. \& Villafuerte, R. (2005). Quarantine length, blood biochemical parameters and survival of translocated European wild rabbits. J. Wildl. Mgmt. 69, 1063-1072.

Calvete, C. \& Estrada, R. (2004). Short-term survival and dispersal of translocated European wild rabbit. Improving the release protocol. Biol. Conserv. 120, 507-516.

Calvete, C., Estrada, R., Lucientes, J., Osacar, J.J. \& Villafuerte, R. (2004a). Effects of vaccination against viral haemorrhagic disease (VHD) and myxomatosis on longterm mortality rates of European wild rabbits. Vet. Rec. 155, 388-392.

Calvete, C., Estrada, R., Osacar, J.J., Lucientes, J. \& Villafuerte, R. (2004b). Short-term negative effects of vaccination campaigns against myxomatosis and viral haemorrhagic disease (VHD) on the survival of European wild rabbits. J. Wildl. Mgmt. 68, 198-205.

Calvete, C., Estrada, R., Villafuerte, R., Osacar, J.J. \& Lucientes, J. (2002). Epidemiology of viral haemorrhagic disease and myxomatosis in free-living population of wild rabbits. Vet. Rec. 150, 776-782.

Calvete, C., Pelayo, E. \& Sampietro, J. (2006). Habitat factors related to wild rabbit population trends after the initial impact of rabbit haemorrhagic disease. Wildl. Res. 33, 467-474.

Calvete, C., Villafuerte, R., Lucientes, J. \& Osacar, J.J. (1997). Effectiveness of traditional wild rabbit restocking in Spain. J. Zool. (Lond.) 241, 1-7.

Catalan, I., Rodriguez-Hidalgo, P. \& Tortosa, F. (2008). Is habitat management an effective tool for wild rabbit (Oryctolagus cuniculus) population reinforcement? Eur. J. Wildl. Res. 54, 449-453.

Cooke, B.D. \& Berman, D. (2000). Effect of inoculation route and ambient temperature on the survival time of rabbits, Oryctolagus cuniculus (L.), infected with rabbit haemorrhagic disease virus. Wildl. Res. 27, 137-142.

Cooke, B.D. \& Fenner, F. (2002). Rabbit haemorrhagic disease and the biological control of wild rabbits, Oryctolagus cuniculus, in Australia and New Zealand. Wildl. Res. 29, 689-706.

DelGiudice, G.D., Mech, L.D. \& Seal, U.S. (1990). Effects of winter undernutrition on body composition and physiological profiles of White-Tailed Deer. J. Wildl. Mgmt. 54, 539-550.

Delibes, M. \& Hiraldo, F. (1981). The rabbit as prey in the Iberian Mediterranean ecosystems. In Proceedings of the World Lagomorph Conference: 614-622. Myers, K. \& MacInnes, C.D. (Eds) Ontario: University of Guelph and Wildlife Research, Ministry of Natural Resources.

Delibes-Mateos, M., Ferreras, P. \& Villafuerte, R. (2009). European rabbit population trends and associated factors: a review of the situation in the Iberian Peninsula. Mamm. Rev. 39, 124-140.

Fernandez, N. (2005). Spatial patterns in European rabbit abundance after a population collapse. Landsc. Ecol. 20, 897-910.

Ferrer, M. \& Negro, J.J. (2004). The near-extinction of two large European predators: the super-specialists pay a price. Conserv. Biol. 18, 344-349.

Fullagar, P.J. (1977). Observations on myxomatosis in a rabbit population with immune adults. Aust. Wildl. Res. 4, 263-280.

Griffith, B., Scott, M., Carpenter, J. \& Reed, C. (1989). Translocation as a Species Conservation tool: Status and Strategy. Science 245, 477-480. 
Griffith, B., Scout, M., Carpenter, J.W. \& Reed, C. (1993). Animal translocations and potential disease transmission. J. Zoo. Wildl. Med. 24, 231-236.

Harder, D.J. \& Kirkpatrick, L.R. (1994). Physiological methods in wildlife research. In Research and management techniques for wildlife and habitats: 275-306. Bookhout, T.A., (Ed.) Bethesda: The Wildlife Society.

Heisey, D.M. \& Fuller, T.K. (1985). Evaluation of survival and cause-specific mortality rates using telemetry data. J. Wildl. Mgmt. 49, 668-674.

Jacobson, H.A., Kirkpatrick, R.L. \& McGinnes, B.S. (1978). Disease and physiologic characteristics of two cottontail populations in Virginia. Wildl. Monogr. 60, 5-53.

Letty, J., Aubineau, J., Marchandeau, S. \& Clobert, J. (2003). Effect of translocation on survival in wild rabbit (Oryctolagus cuniculus). Mamm. Biol. 68, 250-255.

Letty, J., Marchadeau, S., Reitz, F., Clobert, J. \& Sarrazin, F. (2002). Survival and movements of translocated wild rabbits (Oryctolagus cuniculus). Game Wildl. Sci. 19, $1-23$.

Letty, J., Marchandeau, S., Clobert, J. \& Aubineau, J. (2000). Improving translocation success: an experimental study of anti-stress treatment and release method for wild rabbits. Anim. Conserv. 3, 211-219.

Lombardi, L., Fernandez, N., Moreno, S. \& Villafuerte, R. (2003). Habitat-related differences in rabbit (Oryctolagus cuniculus) abundance, distribution, and activity. J. Mamm. 84, 26-36.

Macdonald, D.W., Tattersall, F.H., Rushton, S., South, A.B., Rao, S., Maitland, P. \& Strachan, R. (2000). Reintroducing the beaver (Castor fiber) to Scotland: a protocol for identifying and assessing suitable release sites. Anim. Conserv. 3, 125-133.

McKillop, I.G., Butt, P., Lill, J., Pepper, H.W. \& Wilson, C.J. (1998). Long-term cost effectiveness of fences to manage European wild rabbits. Crop Prot. 17, 393-400.

McPhee, S.R., Berman, D., Gonzales, A., Butler, K.L., Humphrey, J., Muller, J., Waddington, J.N., Daniels, P., Koch, S. \& Marks, C.A. (2002). Efficacy of a competitive enzyme-linked immunosorbent assay (ELISA) for estimating prevalence of immunity to rabbit haemorrhagic disease virus (RHDV) in populations of Australian wild rabbits (Oryctolagus cuniculus). Wildl. Res. 29, 635-647.

McPhee, S.R., Butler K, L., Kovaliski, J., Mutze, G., Capucci, L. \& Cooke, B.D. (2009). Antibody status and survival of Australian wild rabbits challenged with rabbit haemorrhagic disease virus. Wildl. Res. 36, 447-456.

Moorhouse, T.P., Gelling, M. \& Macdonald, D.W. (2009). Effects of habitat quality upon reintroduction success in water voles: Evidence from a replicated experiment. Biol. Conserv. 142, 53-60.

Moreno, S., Beltran, J.F., Cotilla, I., Kuffner, B., Laffite, R., Jordan, G., Ayala, J., Quintero, C., Jimenez, A., Castro, F., Cabezas, S. \& Villafuerte, R. (2007). Long-term decline of the European wild rabbit (Oryctolagus cuniculus) in south-western Spain. Wildl. Res. 34, 652-658.
Moreno, S., Villafuerte, R., Cabezas, S. \& Lombardi, L. (2004). Wild rabbit restocking for predator conservation in Spain. Biol. Conserv. 118, 183-193.

Moreno, S., Villafuerte, R. \& Delibes, M. (1996). Cover is safe during the day but dangerous at night: the use of vegetation by European wild rabbits. Can. J. Zool. 74, 1656-1660.

Muguruza, R., Simon, M.C., Girones, O., Muzquiz, J.L., Garcia, J., Ortega, C. \& Alonso, J.L. (1993). Enfermedad vırica hemorragica del conejo: determinacion de la minima dosis infectante en la reproduccion experimental por las vias intramuscular y aerosol. Med. Vet. 10, 163-168.

Munoz, G. (1960) Anverso y reverso de la mixomatosis. 1st edn. Madrid, Dirección General de Montes, Caza y Pesca Fluvial, . Madrid, Spain, 58-76.

Pages, A., Artigas, C. \& Espuna, E. (1991). Serological profile (by ELISA) of the active and passive immunity on rearing does vaccinated with and oil inactivated vaccine against RHD. International Symposium on RHD, Beijing.

Palomares, F. (2003). Warren building by Europen rabbits (Oryctolagus cuniculus) in relation to cover availability in a sandy area. J. Zool. (Lond.) 259, 63-67.

Ross, J., Tittensor, A.M., Fox, A.P. \& Sanders, M.F. (1989). Myxomatosis in farmland rabbit populations in England and Wales. Epidemiol. Infect. 103, 333-357.

Seddon, P.J., Armstrong, D.P. \& Maloney, R.F. (2007). Developing the science of reintroduction biology. Conserv. Biol. 12, 303-312.

Seddon, P.J. \& Ismail, K. (2002). Influence of ambient temperature on diurnal activity of Arabian oryx: Implications for reintroduction site selection. Oryx 36, $50-55$.

Short, J., Kinnear, J.E. \& Robley, A. (2002). Surplus killing by introduced predators in Australia, evidence for ineffective anti-predator adaptations in native prey species? Biol. Conserv. 103, 283-301.

Simon, M.C., Girones, O., Alonso, J.L., Muzquiz, J.L., Garcia, J., Ortega, C. \& Muguruza, C. (1993). Enfermedad virica hemorragica en conejo industrial: eficacia de una vacuna inactivada en la proteccion frente a la inoculacion experimental. Med. Vet. 10, 44-48.

Soriguer, R.C. (1988). Alimentacion del conejo (O. cuniculus L, 1758) en Donana. SO, Spain. Doñana Acta Vert. 15, 141-150.

Stirrat, S.C. (2003). Body condition and blood chemistry of agile wallabies (Macropus agilis) in the wet-dry tropics. Wildl. Res. 30, 59-67.

Temple, S.A. (1987). Do predators always capture substandard individuals disproportionately from prey populations? Ecology 68, 669-674.

Therneau, T.M. \& Grambsch, P.M. (2001). Modeling survival data: extending the Cox Model. 2nd edn. New York: Springer-Verlag.

Viggers, K.L., Lindenmayer, D.B. \& Spratt, D.M. (1993). The importance of disease in reintroduction programmes. Wildl. Res. 20, 687-698.

Villafuerte, R. (1994). Riesgo de predación y estrategias defensivas del conejo, Oryctolagus cuniculus, en el Parque 
Nacional de Doñana. PhD thesis, University of Cordoba, Spain

Villafuerte, R., Calvete, C., Blanco, J.C. \& Lucientes, J. (1995). Incidence of viral hemorrhagic disease in wild rabbit populations in Spain. Mammalia 59, 651-659.

Villafuerte, R., Lazo, A. \& Moreno, S. (1997). Influence of food abundance and quality on rabbit fluctuations: conservation and management implications in Donana National Park (SW Spain). Rev. Ecol. (Terre Vie) 52, 345-356.

Villafuerte, R. \& Moreno, S. (1997). Predation risk, cover type, and group size in European rabbits in Donana (SW Spain). Acta Theriol. 42, 225-230.
Warren, R.J. \& Kirkpatrick, R.L. (1978). Indices of nutritional status in cottontail rabbits fed controlled diets. J. Wildl. Mgmt. 42, 154-158.

Wolf, M.C., Griffith, B., Reed, C. \& Temple, S.A. (1996). Avian and mammalian translocations: Update and reanalysis of 1987 survey data. Conserv. Biol. 10, 1142-1154.

Woodford, M.H. \& Rossiter, D.P.B. (1993). Disease risks associated with wildlife translocation projects. Rev. Scient. Tech. Office Int. Epizoot. 12, 115-135. 